\title{
Combining Microhistorical and Field Theory Approaches
}

\section{Lay Popular Religious Practice in England during the Long Fifteenth Century}

\author{
Elisabeth Salter \\ University College Dublin \\ elisabeth.e.salter@ucd.ie
}

\begin{abstract}
The purpose of this article is to explore the frictions and potentials endemic in combining microhistorical and field theory approaches, using popular religion in England in the long fifteenth century as an example. In two case studies, concerning basic catechetical texts and the last wills and testaments created by a wide spectrum of the population, the article analyzes how micro- and macro-historical investigation can be tied together. Crucially, micro examples do not simply illustrate but rather add to our knowledge of the general picture. Where micro examples offer a corrective to a general picture there is potential for friction. However, the article also proposes that it is valuable to use Bourdieusian concepts of the cultural field to inventorize the micro evidence in the process of understanding historical situations and transitions more broadly.
\end{abstract}

\section{Keywords}

microhistory - manuscript studies - laity - clergy - lay devotion - England - catechisms - last will and testament

\section{Introduction}

The purpose of this article is to explore the frictions and potentials endemic in combining microhistorical approaches with a framework indebted to theories of the religious field. ${ }^{1}$ I apply this discussion to my own research which

1 See the introduction to the overall thematic section, "The Religious Field during the 
focuses on popular religion in England in the long fifteenth century. I investigate the nature and experience of popular religion through the evidence for popular religious literacy and reading including the basic catechetical texts that were available to the widest spectrum of society in the long fifteenth century, and the written text of the last will and testament which was created by a wide spectrum of the population. At the core of my research is the proposition that surviving texts used and read by the people are a valuable guide to the religious ideas that circulated during the long fifteenth century. I find it productive to look closely at such texts, now surviving as manuscript and documentary evidence. The purpose of looking closely is specifically to elucidate aspects of popular religious practice and experience on the eve of the English Reformation. My research is microhistorical in that I am content to examine, for example, one poem in a number of manuscript contexts, the significance of a single word in a specific codex, changes of wording in comparative examples of "the same" text, or the usage of specific descriptive terminology in one last will and testament document. The purpose of working on such micro examples is never, however, simply to identify tiny isolated instances of popular religious practice that cannot relate to a wider set of issues but rather, always, to understand these instances as key examples of a broader cultural dynamic, and, indeed, to understand these examples as essential to the production of a meaningful context for the broader issues of historical reconstruction including change and transition. In this case, the cultural dynamic is concerned with what fifteenth century people believed, how they encountered their religion, and the ways that these encounters informed their lives including the potential for experiencing new ideas and practising new behaviours.

Micro evidence is useful in itself, but in order to gain a fuller understanding of a cultural context or situation, it is valuable to extrapolate out from the micro examples with the purpose of gaining a more general and a more nuanced understanding of a cultural situation and the ways it is changing. Here lies the potential of combining microhistorical reconstruction with more generalizing (macro) propositions such as field theory. Field theory is understood, in general terms, as "the conscious mapping of relations between different actors $[\ldots]$ engaged in [...] struggle." This general definition encompasses the constant motion of the relations of power in the religious field, as well as the potential for the "reconfiguration" of a field, which implies more wholesale

Long Fifteenth Century. Framing Religious Change beyond Traditional Paradigms," in this issue.

2 See Sita Steckel, "Historicizing the Religious Field. Adapting Theories of the Religious Field for the Study of Medieval and Early Modern Europe," in this issue, 339. 
change during times of, in this instance, transitions in religious culture. ${ }^{3}$ In this article I will demonstrate this potential.

As this article is specifically about potential uses of microhistory in combination with field theory, it seems appropriate to allow a discussion of the nature and genealogy of microstudy in the first instance. Still, in my opinion, one of the most important and thoughtful summaries of what microstudy entails and how it came about is Carlo Ginzburg's "two or three things I know about it" piece in Critical Inquiry (1993). ${ }^{4}$ Here Ginzburg, with particular reference to the Italian School of "Microhistoria," describes the rise of this school of interpretation in reaction to the quantitative approach of, for example, the Annales School. ${ }^{5}$ Ginzburg runs through the influence of Serial History with its interest in ethnology for the potential of studying repetitions in behaviour over time yet at the same time its rejection of an ethnographic focus on a single event in favour of approaches allowing comparison. ${ }^{6}$ Ginzburg reminds us of the significance of Historical Anthropology during this period (1970s and 8 os) for Annales School approaches to mentalité as well as for the development of micro approaches (and important oppositions to capitalism in the "history from below" movement as exemplified in the work of Philip Aries). ${ }^{7}$ In his summary of the divergence between Serial and Micro approaches, Ginzburg proposes that the intellectual price is high for Serial History with its requirement to study only evidence that is repetitive - as he notes, this is particularly difficult with medieval history as much of the evidence is fragmentary. But for Ginzburg the most serious problem with Serial History is its need to look at "facts" only in relationship to the series, that they become valuable only in relative terms. While he acknowledges that historical knowledge invariably involves the construction of documentary series, he is concerned with the fate of the "anomalies that crop up in the documentation." Francois Furet, a lead proponent of Serial History, had proposed ignoring the anomalies because they are "not usable in the perspective of serial history," and this is clearly a limitation for studying the multivalent nature of, for example, social change and the actions of particular cultural agents. ${ }^{8}$

3 Ibid., 342.

4 Carlo Ginzburg, "Microhistory: Two or Three Things that I Know About It," Critical Inquiry 20.1 (1993), 10-35.

5 Ibid., 17.

6 Ibid., 18-19. Ginzburg also acknowledges the significance of the lead proponent of Serial History Francois Furet's work for microhistory, suggesting that Italian Microstoria began with similar concerns to Furet but arrived at a different destination.

7 Ginzburg, "Two or Three Things" (see above, n. 4), 20.

8 Ibid., 41. 
The issue of the anomaly has been central to microhistorical approaches and with Ginzburg as one of its main influences, his narration of the life of the miller of Friuli in the Cheese and the Worms has been a primary influence in developing this school of thought which has legitimized the study of subjects otherwise often not thought worthy of consideration. ${ }^{9}$ Ginzburg characterizes The Cheese and the Worms in a way which hints at a central preoccupation with the ability of a single anomalous voice to make a contribution to our understanding of the broader narrative. He wrote: "In reducing the scale of observation, that which for another scholar could have been a simple footnote in a hypothetical monograph on the Protestant Reformation in Friuli was transformed into a book."10

In his discussion of the nuances of difference between narrative history (that teleological approach of the nineteenth century against which all the above historians and movements were rebelling) and the telling of narrative that includes uncertainties (in the way that his story of Menocchio does), Ginzburg draws out the ways that the anomaly is just as much part of the general picture (or "the context") as is the more routine and expected. His proposal, in consideration of the work of the "nonprofessional Historian" Siegfried Kracauer and the influence of Marc Bloch on Kracauer, is that we need to pursue the reconciliation between the macro- and the micro-levels because of the differing potentials of each. Ginzburg stresses that "A close-up look permits us to grasp what eludes a comprehensive viewing, and vice versa."1l This proposition about the different potentiality of the macro and the micro arises from the ontological point drawn out from Marc Bloch's influential work on peasant society that: "reality is fundamentally discontinuous and heterogeneous. Consequently, no conclusion attained apropos of a determinate sphere can be transferred automatically to a more general sphere (what Kracauer calls the 'law of levels')."12

Turning artfully to the self-conscious construction of any historical narrative, including his own construction of this historiography of microhistory in "two or three things," Ginzburg addresses, finally, the connections and disjunctures between microhistory and some forms of postmodernism. ${ }^{13}$ After reminding us of the fact that documents about events are not the events them-

9 Carlo Ginzburg, The Cheese and the Worms: The Cosmos of a Sixteenth Century Miller, trans. J. and A. Tredeschi (London, 1981).

10 Ginzburg, "Two or Three Things" (see above, n. 4), 22.

11 Ibid., 26.

12 Ibid., 27.

13 Ibid., 28. 
selves and that the perspectives of specific narrative sources vary, Ginzburg addresses what I believe to be one of the most necessary areas of distinction for understanding more about the uses of microhistory: this is the perceived (mistaken) connection between a postmodernism which focuses on the minute fragments as if in splendid isolation and the micro study for which the insistence on the wider context is at the very core of the operation. Ginzburg uses Ankersmit's History and Theory to illustrate this point. Ankersmit's metaphor, which is helpful here, is that whereas the traditional historian was interested in the branch and trunk, the postmodernist is set free to consider the leaves without worrying about the greater parts of the tree (i.e. the context). As Ginzburg points out, the individuals who gave rise to the microhistorical school of thought that he represents had in common an "insistence on context, exactly the opposite of the isolated contemplation of the fragmentary advocated by Ankersmit." But Ginzburg also makes it clear that his and other microhistorians' disavowal of the relativist position supported by the postmodern mode of Ankersmit (because it reduces "historiography to a textual dimension, depriving it of any cognitive value"), is not in tension with "the definite awareness that all phases through which research unfolds are constructed."14

Ginzburg finishes "Two or Three Things" with a return to the issues of heterogeneity:

As Kracauer had already foreseen, the results obtained in a microscopic sphere cannot be automatically transferred to a macroscopic sphere (and vice versa). This heterogeneity, the implications of which we are just beginning to perceive, constitutes both the greatest difficulty and the greatest potential benefit of microhistory. ${ }^{15}$

It is useful to finish the discussion of Ginzburg's "manifesto" for microhistory with a mention of heterogeneity, partly because it would seem ironic to claim that there is one way of doing microhistory and one only. I do want to stress in this article, however, that I am agreeing with Ginzburg's version of microhistory and therefore not with some others. ${ }^{16}$ It is also helpful to return to

14 Ibid., 31-32. For other discussions of postmodernism which appear to misconstrue the value and nuance of the linguistic turn see, for example, Alex Walsham, "Migrations of the Holy: Explaining Religious change in Medieval and Early Modern Europe," Journal of Medieval and Early Modern Studies 44.2 (2014), 241-28o, there 259; Raphael Samuel, "Reading the Signs II: Fact Grubbers and Mind Readers," History Workshop 33 (1992), 220-251, there 243 .

15 Ginzburg, "Two or Three Things" (see above, n. 4), 33.

16 For example, see Catherine Gallagher and Stephen Greenblatt, Practising New Historicism 
"heterogeneity" because the issue raised by Ginzburg of the difficulty of (yet the potential for) the transfer between the micro and the macro is central to the subject of this article-namely the potential and tensions of using both the reduced scale of microstudy and the macro modeling of field theory. This is a point well made by Rob Lutton (in this issue) with regard to the impact of the Holy Name of Jesus whose significance, he suggests, "has tended to be subsumed within wider dominant narratives of late medieval religion without due regard to the micro-processes of the cult's transmission and apprehension." ${ }^{17}$ Lutton identifies that contradictions in understanding the significance of this Europe wide phenomenon, "in part arise from the ways scholars have coopted the Holy Name to their own conceptualisations of large-scale religious change, without fully exploring the micro-mechanisms of transmission of the cult and their relationship to macro-processes of transformation in the religious field."18

When engaging in microhistorical analysis, I employ ethnographic methods drawn from current academic research in order to understand cultural process, in other words the meanings of particular signs or words or events for the people who are experiencing them at the (medieval) time. This is not studying the past "as though it were the ethnographic present"19 but, rather, using the nuanced methods and techniques of modern ethnography as far as possible (obviously one cannot interview or live amongst dead people), in order, through a greater understanding of the contemporary experience of medieval people, to gain access to the dynamics of social and cultural change. This is, in my opinion, a central facet in understanding the long-term transformations and the causations of cultural change to which Alex Walsham refers in her position piece on "Migrations of the Holy."20

It is time to give two case study examples of my own microhistorical approach in order to demonstrate the ways that a use of a macro approach in the form of field theory might contribute. Both cases are concerned with popular religious practice. The first case arises from analysis of the religious literatures that were most widely available to the population in fifteenth century England and the second case is concerned with the Last Will and Testament, one

(Chicago, 2000), 50, 81, for the very different approach of New Historicism which nevertheless claims Microhistory as a significant influence. Jesus and Christocentric Devotion in the Long Fifteenth Century," in this issue, 414.

18 Ibid., 416.

19 Samuel, "Reading the Signs II" (see above, n. 14).

20 Walsham, "Migrations of the Holy" (see above, n. 14), 265. 
of the most widely accessed elements of textual legal discourse in late medieval society, England in this instance.

The example relates to the frequently copied catechetical sequence comprising of texts such as the Ten Commandments, the Pater Noster, the Articles of the Faith, the Vices, Virtues, and Deadly Sins. Various titled works of religious instruction employ this sequence such as the Speculum Christiani, The Lay Folks' Catechism, The Mirror of St Edmund, and the sequence also occurs in numerous manuscripts, often miscellanies, without any particular title. Examples from the miscellany tradition include the manuscript known as the Lincoln Thornton, which is a classic fifteenth-century codex of devotional works and entertainment texts that often carry a moral message. ${ }^{21}$ Another example is Cambridge University Library Ms FF 2 38, described by Eamon Duffy as a "highly stereotyped" collection (because "many of the same items, in more or less the same order, are found in other devotional and didactic collections of the period"). ${ }^{22}$

This sequence of vernacular catechetical instruction is generally understood to have significance because of its connection with the Church's perception of the need to educate the laity. The so called Ignorantia Sacerdotum drawn up under the authority of Archbishop Pecham at the Lateran council of 1281 was designed to be expounded to the laity of the parish four times per year. This was augmented by Archbishop Thorseby in 1357 in the form of an English translation and versification of a group of texts akin to the Ignorantia Sacerdotum. This time it was intended for circulation and teaching amongst the laity. ${ }^{23}$ This

21 See for example, C.R. Goymer, A Parallel Text Edition of the Middle English Prose Version(s) of the 'Mirror of St. Edmund' Based on the Known Complete Manuscripts (Unpublished PhD Thesis, Royal Holloway University of London, 1961); John Thompson, "Another Look at the Religious Texts in Lincoln Cathedral Ms 91," in Late Medieval Religious Texts and their Transmission: Essays in Honour of A.I. Doyle, ed. Alastair J. Minnis, (Cambridge, 1994), 169-187; The Thornton Manuscript (Lincoln Cathedral MS. 91), Introduction by D.S. Brewer and A.E.B. Owen (London, 1975).

22 Eamon Duffy, The Stripping of the Altars: Traditional Religion in England 1400-1580 (Yale, 1992), 70. For a codicological description of this manuscript see Frances McSparran, "Introduction," in Octavian: Edited from Lincoln, Dean and Chapter Library Msg1 and Cambridge University Library Ms Ff 2.38 [The Early English Text Society 289], (Oxford, 1986), 6-9.

23 See also Duffy's description of this process in Stripping (see above, n. 22), 53-55, which implies that the translation and versification organized by Thorseby was named The Lay Folks' Catechism which I think is incorrect. 
group of texts was entitled "The Lay Folks' Catechism," by Simmons and Nolloth in their 1901 edition for The Early English Text Society, and they are widely agreed to represent a significant moment for lay popular religion. ${ }^{24}$ As Vincent Gillespie noted, "Thorseby's instructions are not remarkable for their contents which are commonplace and rudimentary, but because they mark a significant stage in the evolution of the vernacular pastoral manual by conferring official approval on and encouraging the circulation of a vernacular version of his Latin original." ${ }^{25}$

These vernacular catechetical texts, and Thoresby's directives to circulate them, might be an example of the vulgarization process identified by Bourdieu. Although, it is not quite so clear-cut as the example from Richard Rolle cited by Lutton because in its content, the catechetical material does not have the esoteric quality which is described by Bourdieu. However if one accepts the proposition that rendering text previously only circulated in Latin into English might have a demystifying effect, then the "esoteric" descriptor perhaps does apply. ${ }^{26}$ The increased circulation of these vernacular catechetical texts does, however, signal a potential for what Sita Steckel describes as the expanding "size" of the religious field for the laity of fifteenth-century England. ${ }^{27}$

My interest in these manuscripts and texts arose from ongoing work on the ways that late medieval people were able to gain access to religious culture through the written word (often in a mixture of the vernacular-English in this instance - and Latin). In the context of broader work on the history of reading and popular literacy, I wanted to understand more about the ways that literate activity might inform medieval people's religious practice and experiencetheir beliefs indeed. ${ }^{28}$ Always being interested in the fluidities of manuscript culture, and the ways that this opens up possibilities for deliberate or acciden-

24 Thomas Frederick Simmons and Henry Edward Nolloth, eds., The Lay Folks' Catechism: or, The English and Latin Versions of Archbishop Thoresby's Instruction for the People: Together with a Wycliffe Adaptation of the Same, and Corresponding Canons of the Council of Lambeth [Early English Text Society, Original Series 118], (London, 1901).

25 Vincent Gillespie “'Doctrina and Predicacio': The Design and Function of Some Pastoral Manuals," Leeds Studies in English 11 (1980), 36-50, there 43.

26 See also discussion of this in Lutton, "From Micro- to Macro-Processes" (see above, n. 17), in this issue, $426-430$.

27 Steckel, "The Religious Field" (see above, n. 2), in this issue, 357-36o.

28 See for example, Elisabeth Salter, Popular Reading in English c. 1400-1600 (Manchester, 2012); Elisabeth Salter, "Evidence for Religious Reading Practice in Times of Change: Some Models Provided by Late Medieval Texts of the Ten Commandments," in Discovering the Riches of the Word: Religious Reading in Late Medieval and Early Modern Europe, ed. Sabrina Corbellini, Margriet Hoogvliet, and Bart Ramakers [Intersections: Interdisciplinary Studies in Early Modern Culture 38] (Leiden, 2015), 88-110, there 95. 
tal creativity (slight alterations of the wording of a particular element in the catechetical sequence; decisions to exclude some sections; alterations of order; uses of specific decorative devices-however basic these are in the poorer manuscripts - and so on), I have explored the detail of groups of manuscripts containing "the same" (i.e. similar) texts, or the intricacies of one particular codex. ${ }^{29}$ All of these elements of the minutiae of manuscript culture and context are, I have demonstrated, excellent evidence for the ways that these texts are being perceived at the very time in which they are influencing popular religious practice in the conditions of "new literacy" of fifteenth century England. They provide evidence for changes in belief which might resonate with heterodoxy and reforming views, especially in the context of the educationally reforming intention of this catechetical sequence as outlined above. ${ }^{30}$ These examples perhaps provide evidence of the new types of habitus, in Bourdieu's terms, which became available to the laity in the fifteenth century because of the enhanced accessibility to the written text of (albeit basic) catechetical instruction. ${ }^{31}$

Methodologically, I have been informed by the insightful analysis of popular literacy by Johannes Fabian (working on twentieth century Africa) and specifically his proposition about "people writers" - the new literates who are relatively free with grammatical rules and orthography. ${ }^{32}$ I have used Fabian's insights to consider the possibility of "(lay) scribe-readers," lay people who, in the fifteenth century, acquired the opportunity to be involved in the production of their own textual compilations. They may be characterized as more free from the rules binding a professional scribe, making decisions about the emphases of the texts they are copying in a way which may change the anticipated structure or meaning of a text. These changes are sometimes construed as mistakes, but it is more interesting to consider the evidence that such "mistakes" (conscious or

29 For an example of this approach see Elisabeth Salter, "Evidence for Devotional Reading in Fifteenth-Century England: A Comparative Analysis of One English Poem in Six Manuscript Contexts," in Vernacularity in England and Wales, c. 1300-1550, ed. Elisabeth Salter and Helen Wicker [Utrecht Studies in Medieval Literacy17] (Turnhout, 2011), 65-97.

30 See for example my discussion of the significance of word change in two examples of Ten Commandments poems included in the same codex, and the possibilities this raises for readers' interpretations across the spectrum of orthodox to heterodox. Salter, "Evidence for Religious Reading Practice" (see above, n. 28), 103-107.

31 Cf. Lutton, "From Micro- to Macro-Processes" (see above, n. 17), in this issue, 436, in his discussion of the increased circulation of works of religious instruction and its attendant "expansion of the religious field through the fostering of pious and devotional dispositions."

32 Johannes Fabian, "Keep Listening: Ethnography and Reading," in The Ethnography of Reading, ed. Jonathan Boyarin (Berkeley, 1993), 80-97. 
unconscious alterations) gives for "scribal motivation and reader perception." 33 An example is the "non professional" scribe of Oxford Bodleian Ashmole 61 whose copying of the "Sharp Thorns" poem brought in irregularities to the poem's otherwise regular stanzaic structure by changing it from eight stanzas (one for each deadly sin plus a final didactic stanza) to seven stanzas implying a strong sense for this scribe of the significance of "Sevenness" - the seven deadly sins-for the piece. ${ }^{34}$

My use of Fabian's work is not, I note, to pretend that the psyche of my late medieval readers and scribe-readers is the same as the psyche of the new literate in twentieth century Africa, but to use Fabian's excellent analysis as a stimulating comparison. These scribe readers or people writers have some similarity to the Bourdieusian concept of the "independent entrepreneurs" that is identified in Lutton's contribution to this thematic section. ${ }^{35}$ Additionally, and here is a moment where I can demonstrate the integration of cultural context with my micro-study, I include into my understanding of these conditions of manuscript copying and reading, the possibility that pragmatic choices are informing the decision to include an "odd" item within a catechetical sequence: in the sequence in manuscript Cambridge University Library Ff 2 38, the "Seven Virtues Contrary to the Seven Deadly Sins" item is represented by the poem that I have described as the "Sharp Thorns Poem." ${ }^{36}$ It is copied in this manuscript without any clear indication of the stanzaic structure so that it appears on first glance to be another item in the otherwise prose sequence. Aesthetically it corresponds with the "house style" of the remainder of the catechetical sequence of this manuscript, whereby some words are emboldened for emphasis - there is no rubrication. This works well for my analysis as I view the conditions for the "cultural creativity" of the scribe reader as equally informed by pragmatic choices as by individual inspiration. This includes the pragmatic compilation method using fragments from various sources described by Ralph Hanna. ${ }^{37}$ In

33 Salter, "Evidence for Devotional Reading" (see above, n. 29), 95.

34 On the amateur scribe of Ashmole 61 see L.S. Blanchfield, "The Romances in Ms Ashmole 61: An Idiosyncratic scribe," in Romance in Medieval England, ed. Maldwyn Mills, Jennifer Fellows, and Carol Meale (Cambridge, 1991), 65-87, there 80; Salter, "Evidence for Devotional Reading," (see above, n. 29), 95 for my discussion of the significance of the alterations to the "Sharp Thorns" poem.

35 Cf. Lutton, "From Micro- to Macro-Processes" (see above, n. 17), in this issue, 424, in reference to Pierre Bourdieu, "Genesis and Structure of the Religious Field," Comparative Social Research, A Religious Annual. Religious Institutions 13 (1991), 1-44, there 21, 24.

36 Cambridge University Library Ms Ff 238 , fols. 32vb-33ra.

37 The process of compiling catechetical sequences through a gathering of items from various sources, sometimes fragments, is outlined by Ralph Hanna, see for example, Ralph 
his necessarily swift discussion of this manuscript in the magisterial Stripping the Altars - "necessarily swift" because it is not possible to stop at micro detail if one is to encompass such a vast range of evidence in order to make a general overview of traditional religion in England 1400-1580-Duffy cannot pause to discuss the generic qualities of the catechetical sequence in CUL Ff $238 .{ }^{38}$

As one example of the kind of detailed case study I have pursued, I analysed the appearance of that poem (the "Sharp Thorns Poem"), which is a Seven Deadly Sins poem, in its six surviving manuscript contexts to elucidate the varying ways in which it was being used by scribes and readers in the late fourteenth and fifteenth centuries, thereby using the manuscript evidence of the six examples to demonstrate the ways that an analysis of individual manuscripts enhances our understanding of how "specific texts and types of text were perceived, used and read by contemporary [medieval] readers." ${ }^{39}$ To deepen the study of the catechetical sequence in which this "Sharp Thorns" poem plays a part (in CUL Ff2.38 at least), and to pursue the significance of the "fragment compilation process" advanced by Ralph Hanna, an instructive comparison is found between CUL Ff 238 and another manuscript (National Library of Wales, Peniarth 395); here, making particular reference to the seven sacraments element of the catechetical sequence. It is significant that CUL Ff 238 cites The Mirror of St Edmund as a source for that seven sacraments element of the sequence. ${ }^{40}$ Here the particularity of manuscript layout comes to the fore, as the example demonstrates that whereas the text in CUL Ff 238 emphasises the subject of "penance," the Peniarth version of "the same" text within its version of The Mirror of St Edmund, absolutely does not make this emphasis, indeed almost smothering this significant word with a line break (pe/nance). Yes this may seem ludicrously detailed as an example, and it might be difficult to follow (I can assure you it is an art communicating the relevance and significance of these small examples in a conference situation or in a funding bid)—but the larger point here is about the significant role of the visual aesthetic of a specific manuscript in conveying the nuances of meaning (and the emphases that are generated).

Hanna, The Index of Middle English Prose. Handlist XII: Manuscripts in Smaller Bodleian Collections, xx; see also Rob Lutton's reference to the "piecemeal and contingent" processes of gathering material on the Holy Name of Jesus (Lutton, "From Micro- to MacroProcesses" (see above, n. 17), in this issue, 430).

38 Duffy, Stripping (see above, n. 22), 70.

39 Salter, "Evidence for Devotional Reading" (see above, n. 29), 65.

40 Cambridge University Library Ms Ff 2.38, fols. 33vb-34ra, actually identified with the heading "shortly declared of St Edmund of Pounteneye." 
In CUL FF2 38, as noted above, the "house style" of this whole catechetical sequence involves emboldening particular words (there is no illumination); the same style is not present in the Peniarth version (and indeed, as I have already described, there is no effort to emphasise the word and concept "penance"). The larger significance relates to the potential of this basic catechetical material to be "re-formable" - different manuscript styles, and decisions being made about emphasis, can radically alter the nuance of meaning, including the extent to which certain key concepts are emphasized or diminished in significance. I propose this to be an important element in what I call the "poetics of popular religion." This allows for a situation in which multiple perceptions of the meaning of these central catechetical texts are being promulgated at any given time. And, indeed, to return to the concept of "context" - this is the very stuff of cultural context. This point derived from micro-study can be extrapolated out to understand it as a condition in which popular religion, as encountered through manuscript culture, is multivalent and fluid. Maybe we suspect that already using broad sweeps and general pictures (and hindsight), but my point is that here I have specific evidence for that general conclusion. We might also note that this specific evidence gives us some insight into the causes of religious change-in other words the fluidity of textual emphasis enabled by manuscript culture was part of the cause of (the potential for) longer-term religious change..$^{41}$

A second example of adding depth to this case study, still working with the fragment compilation method and its implications, is found in an exploration of the group of texts known as "The Lay Folks' Catechism" (to which the catechetical sequence in CUL Ff 38 is closely related). Given the "re-formability" of this sequence of short texts, the identification of any text as actually and definitely "the Lay Folks' Catechism" is problematic, rather it is better to appreciate "Lay Folks' Catechism" as one sequence amongst a widely circulated group of programmes of vernacular catechesis. ${ }^{42}$ Characteristic of a dominant interest in defining Lollard texts in the late nineteenth century, when the Early English Text Society edition of The Lay Folks' Catechism was produced, Simmons and Nolloth identified a specifically "Wycliffite adaptation" of the catechism (Lambeth Palace Ms 408), which is produced in their EETS edition in parallel with their example of the orthodox and in their terms "original" text

41 See Walsham, "Migrations of the Holy" (see above, n. 14), 252.

42 On this subject see Elisabeth Salter, "Miscellaneity in Practice: A further Look at the English Text known as The Lay Folks' Catechism," in Medieval Translator, ed. Pavlína Rychterova (forthcoming 2020). 
described as "Archbishop Thoresby's instruction or catechism for the people from the authentic copy in his register at York." ${ }^{33}$ In keeping with more recent historiographical trends, ascribing wholly Wycliffite or Lollard status to specific versions of the "Lay Folks' Catechism" has been criticized in subsequent scholarship. A leading scholar in this field, Anne Hudson, has commented that the traditional identification of Lollard texts has "a grain of truth to several of error or at least to several of oversimplification." ${ }^{44}$ Yet, there has remained an interest in what might constitute heterodox content in this sequence. This interest is testament, perhaps, to the long-term significance which is attributed to these catechetical sequences for the programme of education and vernacularisation that took place in the long fifteenth century. More importantly, perhaps, for this discussion is the implied acknowledgement of the role of popular vernacular religious literature in the long process of reform contributing to the English Reformation. ${ }^{45}$ So, just to stress, the significance of this type of vernacular catechetical literature for (and in the causation of) major historical events such as Reformation has been widely considered. ${ }^{46}$

Snapshots of the way that manuscript-focused micro-analysis can inform our general understanding of popular religious belief can be found in comparisons between various manuscript witnesses ascribed with the identity of "Lay Folks' Catechism." ${ }^{47}$ For example, bearing in mind the ongoing interest in the potential for non-orthodox content and how that might be ascertained, it is interesting to take a closer look at one of the main witnesses, British Library Add Ms. 24202. This manuscript has in full the instruction to receive the sacrament once a year at Easter after confession. ${ }^{48}$ This section has been identified

43 Simmons and Nolloth, eds., The Lay Folks' Catechism (see above, n. 24), 1. This is Archbishop Thoresby's Register (Borthwick Institute of Historical Research, York), fols. 295r297v.

Anne Hudson, "A New Look at the Lay Folks' Catechism," Viator 16 (1985), 243-258, there 243 .

45 For the classic text on the long process of religious reform in England see Anne Hudson, The Premature Reformation: Wycliffite Texts and Lollard History (Oxford, 1988); note also Eamon Duffy's identification of the role of religious text in the rise of lay literacy in fifteenth-century England, although he is certain that this does not imply a rising tide of reform; Duffy Stripping (see above, n. 22), 207-287 and passim.

46 Walsham, "Migrations of the Holy" (see above, n. 14), 252.

47 See Sue Powell, "The Transmission and Circulation of The Lay Folks' Catechism," in Late Medieval Religious Texts and their Transmission, Essays in Honour of A.I. Doyle, ed Alastair J. Minnis (Cambridge, 1994), 67-84, there 72, n. 20; Hudson, "A New Look" (see above, n. 44), 249, 257.

48 British Library, Add 24202, fol. 36 r. 
by Hudson as "repugnant to anyone with Lollard sympathies" as it "clearly implies by its repetition of the 1215 Lateran Council provision, the acceptance of the orthodox doctrine which the Lollards disputed." 49 So from this evidence we might assume therefore that Add 24202 must be an orthodox version of the "Lay Folks' Catechism." However, if we observe the manuscript context for Add 24202 we note that it contains within it "The Tretise of miraclis pleyinge," one of the better known Wycliffite treatises. ${ }^{50}$ And, even a cursory look at this manuscript strongly indicates that the two texts are written in the same hand, into the same codex, with the same (minimal) decorative features and therefore the same "house style." A different example, also drawn from the Lay Folks' Catechism corpus, gives another perspective on the multivalency of basic catechetical texts that have been identified as part of the canon of "Lay Folks' Catechism." In Lincoln Ms 66, which is a preaching manual with mainly Latin contents, most of which provide short biblical quotations for specific theological points, there is a short text in English which has been identified as an extract from The Lay Folks Catechism. ${ }^{51}$ This is the "Articles of the Belief" section as it is entitled in the Early English Text Society edition. Of the fourteen, nine articles are represented in Lincoln 66 and there is an extensive and particular focus on the Trinity. A comparison of Lincoln 66 and the EETS ("authentic") versions gives a taste of this:

Lincoln Ms 66:52

Ye fyrst point is yt we schalt trow ye holy [Amen-from previous text $]$ / and undividyd trynyte fad[er] and sone and ye holy gost/ one god almighty and all $y$ e godhed in ye trynitye to geddyr / shew being ever substacyall togedyr eve[er] ev[er]lastand / as mageste maker of all creatures of ilkam \&b be ilkam \& / in ilkam all thynges are $y \mathrm{t}$ are in hevyn \& in erthe vys /sybyll and invysybyll bodily and gostely

EETS version:53

49 Hudson, "A New Look" (see above, n. 44), 255.

50 British Library, Add 24202, fol. 14r and noted by Hudson, "A New Look" (see above, n. 44), n. 18, 5 that: "The other contents of this manuscript are Lollard or show some sympathy with Lollardy." See Anne Hudson, ed., Selections from English Wycliffite Writings (Cambridge, 1981).

51 R.M. Thomson, ed., Catalogue of the Manuscripts of Lincoln Cathedral Chapter Library (Cambridge, 1989), 65 .

$5^{2}$ Lincoln Cathedral Ms 66, fols. 104v-105r.

53 Simmons and Nolloth, eds., Lay Folks' Catechism (see above, n. 24), 22, 24. 
The first poynt that we sal trowe of the godhede is to trowe stedefastly in a trew god and that nane othir is for to trowe in [...]

The fift point is that the trinitie Fadir and Sone and haligast thre persons and a god is maker of heven and erthe and of all things

What these examples demonstrate is the ways that a close look at the detail of not only textual content but also manuscript context can support a theory about the multivalent experience of fifteenth century vernacular piety, whereby, in the BL Add 24202 example, individuals may well have encountered (or copied) what we would consider to be avowedly orthodox and clearly heretical material in the same manuscript book and whereby, in the Lincoln 66 example, the texts of popular religion themselves had the potential for immense variability despite their identity as tenets of the Christian faith. The broader point from these small examples concerns the possibilities for encountering multiple versions of religiosity in the cultural conditions of fifteenth century lay belief and practice as experienced through a manuscript culture of widely circulated text. This set of conditions is, I suggest, all the more interesting when it applies to basic (catechetical) text, which ought to comply with an unchanging set of tenets. The potential for multiple versions of specific instructional texts that I describe briefly here is akin to Lutton's view regarding another branch of increasingly circulated religious text that "the emergence of a Holy Name canon occurred unofficially, haphazardly and associationally, and is observable only at the micro-level." As Lutton notes, Bourdieu also identifies an issue of significance for our understanding of the interplay of macro/micro which is that religious movements such as the Holy Name (or in my examples the promulgation of catechism for the education of the laity) "only give the appearance of unity and work to conceal the great diversity of practice, experience and interpretation that is only identifiable in 'micro-mechanisms of cognition and communication'." 54

\section{$3 \quad$ Case Study 2: The Last Will and Testament}

This example relates to the ways that looking at the details of individual will documents, or small clusters of documents, contributes significantly to our understandings of late medieval popular religion. My approach to the last will

54 Lutton, "From Micro- to Macro-Processes" (see above, n. 17), in this issue 438, in reference to Bourdieu, "Genesis and Structure of the Religious Field" (see above, n. 35), 29. 
and testament has been underpinned by the micro-historical ethos already discussed and indeed, I have found that a close study of wills complements the detailed analysis of the basic texts of religious reading that are discussed in the first case study. My founding hypothesis about the last will and testament revolved around the concept of cultural creativity, in which I used a corpus of approximately 1000 wills made $\mathrm{c} 145^{\mathrm{O}}-15^{6} \mathrm{o}$ to postulate that the individual testator engaged in a creative process of construction during the making of a will. ${ }^{55}$ There are methodological caveats which I have rehearsed elsewhere, but the overwhelming evidence for my hypothesis was that a will, a text made during or in consideration of a most significant moment in the life cycle, should be treated holistically and understood to create its own symbolic sphere in which, for example, descriptive words and phrases "mean" particularly and specifically in the context of that text. I have used the example of one will text, that of John Aunsell, a merchant tailor and citizen of London dwelling in Southwark, made in 1516 , to illustrate this. This is an interesting will with very much detail but it is not abnormal. Its formulaic structure, requests made and bequests given are all entirely conventional. ${ }^{56}$

Using the will of John Aunsell I have demonstrated the ways that this text created a set of symbolic resonances around specific themes and issues; one example being use of the name John. John Aunsell made a number of bequests which related to holy figures by the name of John, for example, he requests that a sermon of the life of John the Baptist be created and delivered some time after his death, he gives money to the brotherhood of St John the Baptist (of the merchant tailors) in the church of his burial, St Mary, Southwark, and he also requests for his body to rest by the master and fraternity in that church immediately after his death and gives portions of money for the obituary services, the placing of his name in the bede roll and repairs to the merchant tailors' hall in London. To ensure that this provision is met he entwines another brotherhood of St John, this time in Ashwell, Hertfordshire (where Aunsell has property and family) by giving his house and land in Ashwell to the fraternity of St John the Baptist based there on the condition that they pay 20 shillings yearly to the fraternity of St John at Southwark. Here Aunsell is using John-ness as an enduring theme throughout his will text in order to create and ensure various practical and spiritual provisions for himself and his family. His gravestone creates a more visual rendition of the power of the name John in this document, with

55 Elisabeth Salter, Cultural appropriation and transmission in town and country in late Medieval England (Ph.D. diss, University of Kent, 2003); Elisabeth Salter, Cultural Creativity in the Early English Renaissance: Popular Culture in Town and Country (London, 2006). 
its description of the symbol of John the Baptist (and the pelican representing Christ) praying for him, John Aunsell. He requests:

A stone garnished with ii pictures a man and a woman and above that a pictour of the holy lambe with a little scriptour under his fote saying the holy lambe with a picture of the pellycane saying at his foot in a little scriptour the goostely bird saying at his fote from the mannes head the ii Johns pray for the thirde Also the scriptour under the fote of the manne and the woman saying thus saye that this wrytinge reed and see beholde this worlde it is but of vanyte under this marble stone lieth John Aunsell merchant taillour both body and bone for his soule and all Christen soules in the worship of Jesu and the Trinitie say a pater noster and an ave

John Aunsell's request for a lavish stone also gives an insight into the ways that a specific personal request about commemoration can break through the formulaic text of the last will and testament. If one rewrites part of the above request using line breaks, the personalized poetic ditty becomes more clear:

Saye that this wrytinge reed and see

Beholde this worlde it is but of vanyte

Under this marble stone lieth John Aunsell merchant taillour both body and bone

For his soule and all Christen soules in the worship of Jesu and the Trinitie say

A pater noster and an ave

This poetic invention also gives us access to the ways that early sixteenth century individuals experienced and aestheticized commemoration as part of their own personal religious practice. It is very likely that Aunsell's poem was influenced by the types of vernacular devotional writing that were in circulation at the time, some of which are found in the same books as the "Lay Folks' Catechism" text discussed in the first case study. Detailed examination of other last will and testament documents also gives us access to late medieval people's devotional lives and the interactions between the domestic and the devotional. In all cases it is valuable to consider the will text as a whole, to infer the symbolic sphere being created by an individual testator, but it is also instructive to look across multiple surviving texts to get a sense of the local culture of, in this instance, pious experience.

In the corpus of evidence for the East Yorkshire town of Beverley, for example, references to personal devotional practice are noticeably frequent and 
full. Beverley is an interesting location on account of the Minster (the Collegiate church of St John as it was known in the medieval era) and it seems clear from the frequency of requests for specific masses and types of divine service, that parishioners of Beverley and its sister church of St Mary were particularly knowledgeable about liturgy_in particular requests for "mass by note" are noticeably prevalent and this may relate to the role of Beverley Minster in music education, particularly singing. ${ }^{57}$ With regard to daily devotions and their intersections with domestic life, bequests of portable or household altars amongst Beverley residents making their wills between 1380 and 1470 are interesting. John de Ferreby, for example, who made his will in 1470, left his personal altar to his wife as a reward for acting as his executrix:

And I wyll that my wife have for her reward my mess buke and my best chales and the whole Auter with the crewetts and the paxbrede with thys that sche gyffall aftyr hir decese to syche place as we may be prayd for for $\mathrm{ev}[\mathrm{er}] .^{58}$

In 1444 wealthy merchant John Brompton of Beverley also left a personal altar to his grandson, Nicholas. This was probably kept in the room described in the vernacular within this Latin text as the "withdrawyngechamber" and included a missal with silver gilt clasps, worsted vestments in red, pillows, and altar cloths. ${ }^{59}$

Bequests such as John Brompton's provide a glimpse of lay private devotional practice including the spatial arrangements made for this within a house. Gifts of textiles decorated with religious scenes also hint at the ways that the domestic was imbued with lay religious knowledge. Amongst many fine gifts of silver, textiles, and jewelry he gave to his son, Nicholas, an "Arraswork" cloth with the image of the blessed Mary upon it. Depictions of religious scenes of this kind remained precious into the sixteenth century it seems. In 1523, a wealthy widow of Hull called Joan Thurcross left to her main beneficiary "my best feather bed ... with a covering of Ares having the picture of our lady riding into Egypt." ${ }^{\circ 0}$ Again such items give a sense of the colourful world of domestic imagery that combine scenes of a religious nature, as well as of the

See, for example, from the Borthwick Institute, University of York, Robert de Cotyngham (1392) Prob. Reg. 1, fol. 62; John Coldbek (1442) Prob Reg. 2, fol. 76; Thomas White (1453) Prob. Reg. 2, fol. 339; William Hewytt (1468) Prob. Reg. 4, fol. 187.

58 John Ferriby, Borthwick Institute, University of York, Prob Reg. 4, fols. 166r.

59 Brompton 2, fols. $86 \mathrm{r}-89 \mathrm{v}$, at $87 \mathrm{v}$.

6o Joan Thurcrosse (1523), Borthwick Institute, University of York Prob. Reg. 9, fols. 272r-273r. 
perceived connection of these types of goods with overseas cloth production, in this case Arras in France. ${ }^{61}$ And bequests of religious and liturgical books sometimes bridge the gap between domestic devotion and the public sphere of the parish when, for example, a testator requests that their book (or a new book) be kept in the church for public use. In 1458, Thomas Mayne makes such a request with the Antiphoner that he requests be left before the image of St Mary in the Collegiate church at Beverley (the Minster), so that it might be used for singing services on festival days including the feast of the birth of Christ and of St John the Baptist, the Feast of St Michael the Archangel and Easter. ${ }^{62}$

Sometimes a close look at a cluster of will texts can provide specific evidence for particular pious outlooks in one family or group of extended kin. My example, here, is the case of Katherine Henryson and the connections between the Henryson and the Dalton families of Hull and the East Riding of Yorkshire, in which we glimpse what seems (partly perhaps because of survival rates such that other examples have been lost) to be particularly extreme deviation from the usual formula of the pious preamble to a conventional will text.

Katherine Henryson made her will in 1541 and died the same year. Katherine's will clearly identifies her to be part of a cluster of individuals that includes two families of particular interest for the ways they express their pious affiliations: the Daltons and Henrysons (sometimes written as Harrison or Herrison). Katherine Henryson identifies herself very strongly in her will with her first husband John Dalton next to whom she wishes to be buried, in Hull, in the "Trinitie Churche ... in the quere under the through [sic] wher my husbande John Dalton liethe." ${ }^{63}$ It is likely, and assumed in the family tree published by Jenny Kermode in her study of late medieval merchants of the region, that this John Dalton is the individual who died in 1496 and whose will text, alongside that of his brother Thomas (d.1503) contains an extremely interesting pious preamble. ${ }^{64}$ John Dalton and Katherine had nine children: William, Robert, John, Thomas, Anthony, Lawrence, Edward, Anne, and Elizabeth (called Besse in Katherine's will). Katherine's second husband was Robert Henryson ( $\mathrm{d}_{1520}$ ). This must have been a marriage late in the life of Robert and quite late in Katherine's life too (although she survives him by 20 years). It most probably

\footnotetext{
61 Ibid.

62 Thomas Mayne (1458), Borthwick Institute, University of York, Prob. Reg. 2, fol. $368 \mathrm{r}$.

63 Katherine Henryson (1541), Borthwick Institute, University of York, Prob. Reg. 13, fol. 43r. I take the unusual word "through" to indicate a passageway.

64 Jenny Kermode, Medieval Merchants York Beverley and Hull in the Middle Ages (Cambridge, 1998), 89 .
} 
occurred after Katherine's childbearing years. No mention is made of any Henryson children or any other members of the Henryson family in Katherine's will.

The very unusual pious preambles in the last will and testaments of John Dalton (Katherine's first husband) and John's brother, Thomas, are almost entirely the same. There are two other survivals of this preamble-one of which is that of Katherine's second husband Robert Henryson (d 1520). The preamble's fourteen lines that interrupt the customary formulaic content of the opening to the last will and testament indicates a very intense devotional focus. It begins as follows:

I considering and remembering think in my heart that the days of men in this mortal life be but short and that the number of death is in the hand of Almighty God; and that he hath ordained the terms that no man may pass; remembering also that God hath ordained man to die and there is nothing more certain than death and nothing more uncertain than the hour of death ...65

It is plausible to attribute the preamble to an affiliation with a guild (or cult perhaps) of Corpus Christi given the other details within these three documents, although this preamble is apparently distinct and not in common usage by others expressing this affiliation. One example of the stated affiliation to Corpus Christi is the "table of oversea worke" for the Corpus Christi Alter bequeathed by Robert Henryson, in 1520, to the Trinity Church in Hull, "price the same xxxli sterling and the story to be of corpus Xti." 66

We can infer from this cluster of last will and testament documents that Katherine Henryson was deeply involved with the distinct religious affiliation shared by her first and second husbands although the same distinctive preamble is not used by Katherine, perhaps because she is a woman she does not have access to it. However, knowing her family connections with this intense expression of religiosity gives resonance to one small phrase within Katherine's

65 This version of the preamble is taken from the will of John Dalton (1496), Borthwick Institute, University of York, Prob. Reg. 5, fols. $483^{r}-484 v$. This is discussed in Peter Heath, "Urban Piety in the Later Middle Ages: The Evidence of Hull Wills," in The Church, Patronage and Politics in England and France in the Fifteenth Century, ed. R. Barrie Dobson (Gloucester, 1984), 209-234, there 213-214.

66 Robert Henryson (1520), The National Archive, London, Prob. Reg. 11/19, fols. 250v-251r. The "table" is a probably a decorative board perhaps commemorating the names of this Robert and others, alongside the "story" of Corpus Christi. 
own testament. She requests: "Also I will that all the prestes within the towne aforesaide to be at my buriley and to be buried under stole as a faithful christen woman" (my italics for emphasis). Here, it is as if she belongs with, and is stating her allegiance to, an era that is passing in 1541. Given her marriage history, Katherine may have reached a great age and so she seems to be asserting what we associate with late medieval piety at this point on the cusp between the eras we usually think of as being pre- and post-Reformation. The meaning of the reference to being buried under a stole is not entirely clear but it is unusual and it must relate to some part of the (medieval) funerary traditionwhich Katherine's text identifies as being appropriate for a "faithful Christian woman"-again an unusual phrase in this context. Other elements in the wording of Katherine's will indicate her wish to preserve a family identity - and, moreover, her desire to be assertive in this process is indicated in the addition of a clause emphasizing that the bequest is her will. For example, alongside a best piece of silver, Katherine bequeaths to her grandson, John Dalton (the son of Thomas) the house that she dwelled in, plus two other portions of land and their appurtenances. The land is to pass to John after the death of his father with the caveat that "he neyther sell them nor pledge them but they shall remaine from here to here [heir to heir] forever for this is my will" (my italics). And to her daughter, Anne, alongside a rented dwelling house in Saviour's Lane, Hull, Katherine bequeaths "a flate piece with a bowe in the prynte this is my will."67

The small glimpse into Katherine's own distinctive piety comes to the fore because of the cluster of (men's) testaments we can place around her, and this gives an impression of a woman harking back to a form of pious expression that she seemed to feel was in danger of waning by the mid sixteenth century. In this concern she anticipates the changes wrought by the Reformation. But there is also one further addition to the jigsaw, which helps to confirm Katherine's involvement in the continuation, perhaps the transmission, of the distinct and intensive family piety of the Daltons and Henrysons. This is found in the will of one of her sons, Thomas Dalton, which was made in August 1556 (and proved in October of the same year) and it takes the form of the distinctive preamble - word for word the same as that produced in the late fifteenth century by Thomas's father John, his uncle Thomas, and by his step father Robert in 1520. This includes the lines strongly reminiscent of late medieval Catholic piety:

67 Katherine Henryson (1541), Borthwick Institute, University of York, Prob. Reg. 13, fol. 43r. 
... beseeching Almighty God that I may die the true son of holy kirk, of heart truly confessed, with contrition and repentance of all my sins that ever I did since the first hour I was born of my mother into this sinful world unto the hour of my death; of which offences I ask god forgiveness \& in this I beseche the blessed Virgyne Marie and all the companye of heaven to praye for me ... ${ }^{68}$

Katherine Henryson's son, Thomas Dalton, made his last will and testament during the reign of Mary Tudor, which is probably why it was possible for him to express this sentiment so clearly. The timing is a stroke of luck in terms of the evidence Thomas leaves for the continuation of this family piety, and it helps to confirm the significance of the glimpse we gain of his mother's desire to continue with a distinct pious tradition against the tide of change in the 1540s. The nuances of detail in Katherine Henryson's document help to provide a fuller picture of an extended family with very particular ideological interests on the eve of the Reformation. Whereas most of the evidence for these beliefs and practices is found through records left by men from this belief community, the addition of Katherine's side of the story gives a fuller picture of how the beliefs and practices of the Daltons and Henrysons were nurtured and encouraged by this woman's influence. Putting Katherine Henryson's document together with the more overtly phrased religiosity found in her kinsmen's documents also enables us to find in her implicit references a shared community of belief and practice.

\section{4}

\section{Conclusion}

It is my proposition that we must understand these micro-examples as key items of evidence for piecing together the broader picture of popular religious practice and experience and the conditions which may have contributed to the potential for religious change on the eve of the English Reformation. I would suggest also, therefore, that because they provide evidence for potentialities of change, these micro examples do give us evidence towards building an understanding of causation (the causes of religious change on the eve of the English Reformation). The examples in Case study 1 add detailed evidence to

68 Thomas Dalton (1556), Borthwick Institute, University of York, Prob Reg 9, fols. 136r-137r, there fol. $136 r$. 
our understanding of the multivalency of religious belief in the fifteenth century, whereby individuals routinely had access to a wide spectrum of heterodox religious text, and fluid versions of central Christian tenets. The examples in Case study 2 add detailed evidence for our understanding of the ways that symbolic meaning was created and conveyed in one of the most widely accessed texts, the last will and testament. The examples indicate the extent of personal choice in the formation of symbolic resonances in commemoration, with the potential for individuals and families to maintain traditional beliefs despite the tide of reforming change.

I am content for the micro-examples I have described, which I stress construct the very substance of changing religious belief, to be conceptualized in the Bourdieusian terms of a religious field. This is especially the case if we take on board the amendments to Bourdieusian thinking proposed by Sita Steckel, in which we rethink the relations between the cleric and the lay person so that we ascribe more agency to the laity of the fifteenth century, and we take as a given that late medieval religious belief is characterized by "diversity." ${ }^{\prime 9}$ This is a field which is subject to contestation in terms of different forms of belief (i.e. different forms of the basic catechetical text implying differing nuances of belief; differing pious requests implying specific, sometimes controversial, religious allegiances). This is a field where the power relations between the actors in the field are in flux (i.e. rising confidence of the literate laity in the process of interpreting the clerical instructions for the basics of Christian belief) and where there is a strong possibility of movement of the field boundaries (i.e. changing combinations of orthodox and heterodox nuances in the texts I described).${ }^{70}$ It is difficult to decide what shape of field, to use Gorski's terminology, we would be describing, where the shape varies according to the relative strengths of hierarchy and orthodoxy (pyramid, tower, mountains, or box) in order to characterize the "changes in the structured relations between social positions" and where the types of relational change are "genesis, autonomy, size, boundaries and shape."71 Or, indeed what the purpose of this would be. As Gorski points out, Bourdieu's analysis of the field is less concerned with what he describes as the subjective than the objective: Bourdieu's field is less readily applicable to the "symbolic and cognitive constructs" which

69 See Steckel, "Historicizing the Religious Field" (see above, n. 2), 362-363.

$70 \quad$ Ibid., $353^{-} 356$.

71 Philip S. Gorski, "Bourdieusian theory and historical analysis. Maps, mechanisms, and methods," in Pierre Bourdieu and Historical Analysis, ed. P.S. Gorski (Durham, N.C. 2013), $327-366$, there 334 . 
are, arguably, central to the processes of religious practice and experience I am considering in my micro-examples. ${ }^{72}$

However, Bourdieu's adaption of the concept of "capital" for application to the cultural field and its various sub fields is a useful tool even at this micro level. Key forms of capital being "cultural," "symbolic," and "social," each "field" has its own form of capital. ${ }^{73}$ Deciding the identity of the "field" to which this article's micro-examples belongs is a little tricky—but for argument's sake we can label it "lay popular religious practice in the long fifteenth century" and this could incorporate the Holy Name material discussed by Lutton as well as other forms of instructional text, and the massive corpus of surviving will texts. This is a reconfiguring field during the fifteenth and early sixteenth centuries as we know with hindsight in the run up to the English Reformation, and also as the people living through the time knew themselves and witnessed through their interactions with the multivalency of the religious expressions that I have described. If, as Gorski suggests, a central issue in Bourdieusian capital theory is that the creation and legitimation of capital involves considerable symbolic work and various symbolic processes, then it is possible to extrapolate from the instances of changed words and the specifics of manuscript context to suggest that while the Church's instruction to enhance the circulation of vernacular catechesis to the laity confers on those texts a sort of cultural capital, symbolic capital in terms of the meanings of these multivalent versions of catechesis is constructed through word choice and the nuances of layout (and their transformation for different iterations). Similarly, while the will text is an official legal instrument that includes statements of personal religious affiliation as an expression of its cultural capital, the symbolic capital of individual texts is created by nuances of request and symbolic referents constructed by the testator for the purposes of generating meaning within that individual text.

The processes that Gorski outlines for the generation of symbolic capital are "abstraction, codification, commensuration, measurement, ranking." If we take "codification," for example, to be a central process in the production of the written text of catechism or last will and testament; ${ }^{74}$ and the nuances of changed word or altered layout to be a significant (micro) process within the action identified as "codification," then it is fair to say that microhistorical analysis, as I have defined it here, can assist with the central task of a "Bourdieusian approach to

72 Ibid., 334 .

73 Ibid., 338 .

74 Here we need to assume the corrective to Bourdieu's sense of the specialist and the layperson as proposed by Steckel, "Historicizing the Religious Field" (see above, n. 2), 347-348, citing Bourdieu, "Genesis and Structure," p. 31. 
historical analysis" which is to "inventorize these processes, track their transformations, and detail their workings for each of the various types and subtypes of capital." 75

As Ginzburg's description of microstoria points out, it is of crucial importance to understand that the micro examples do not simply add colour to the general picture but rather, they may make correctives to the general narrative thereby adding nuance and knowledge to our understanding of a historical moment or period as well as the reasons for change and transition. At the same time, to be able to generalize from many particularities, to "inventorize" processes and their changes within a cultural field, is of definite importance when it comes to understanding a larger picture of religious practice and belief across England on the eve of the Reformation and more broadly across the countries of Europe.

75 Gorski, "Bourdieusian theory" (see above, n. 71), 344. 